\author{
Military Technical College \\ Kobry Elkobbah, Cairo, \\ Egypt.
}

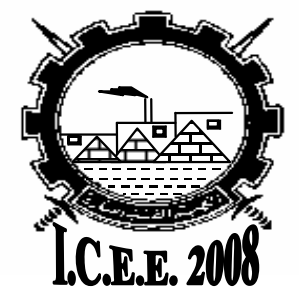

$4^{\text {th }}$ International Conference On

Chemical \& Environmental

Engineering

27-29 May 2008

\title{
TOUGH POLYBENZOXAZINE-CLAY NANOCOMPOSITES THROUGH ONE SHOT METHOD
}

\author{
Tarek Agag, Ahmed Akelah, Ahmed Rehab and Salwa Mostafa*
}

\begin{abstract}
A series of tough polybenzoxazine-clay nanocomposites were prepared by novel method from organo-montmorillonite (OMMT) and bifunctional benzoxazine, bis-(3dodecyel-3,4-dihydro-2H-1,3-benzoxazine) isopropane (B-dod). Benzoxazine monomer was in-situ formed in presence of organoclay. OMMT was prepared by modification of NaMMT with ammonium salts of amines such as tyramine (Tyr), aminolauric acid (ALA) and N,N-dimethylstearylamine. The thermal induced ring opening polymerization of hybrid materials was followed by DSC and IR. DSC indicted that, OMMT was effective to lower the temperature of ring opening polymerization of the monomers in comparison with the neat resin (B-dod). DSC confirmed that, the using of one shot process was more effect and processability than the traditional method (blend). The X-ray diffraction analysis indicated that organoclay was exfoliated into polybenzoxazine up to the higher content $(20 \%)$. The hardness of the hybrid was evaluated, showing the effectiveness of the clay to give hard hybrid nanocomposites. The tensile properties of hybrid were examined, as the content of clay modified increase, the tensile modulus increase, however, the elongation at break decreased. Thermogravimetric analysis indicated that the nanocomposites have higher decomposition temperatures than that of the neat polybenzoxazine. Furthermore the char yield was shifted to the highest content because of the presence of clay loading.
\end{abstract}

\section{KEY WORDS}

Tough polybenzoxazine, nanocomposites, organically, hardness 


\section{INTRODUCTION}

Polymer-clay nanocomposites attracted great interest because they often exhibit remarkable improvement in materials properties when compared with neat polymer or conventional composites. These improvements include high moduli and strength [1-3], heat resistance and reduced flammability [4,8-10], decreased gas permeability [5-7] and increased biodegradability of biodegradable polymers [11]. The morphology of clay as platy materials is characterized by a thickness of about one nanometer and the other two dimensions are in the range of 100-1500 nanometers. This aspect ratio dominates the interaction of these materials with polymers. The clay is normally hydrophilic in nature and will disperse into aqueous solutions forming gels. This hydrophilic character makes it suitable for good desperation in polymer systems that are water soluble such as polyvinylalcohol, polyethylene oxides, and polyvinylpyrrolidone. However, the miscibility of hydrophilic clay with water insoluble monomers or polymer is restricted. In order to render clay compatible with hydrophobic polymers, ion exchange reactions utilizing organic onium ions are employed. The resulting surface modified clay will be more hydrophobic and compatible with hydrophobic polymers [12].

Polybenzoxazine as a novel phenolic resin has varieties of interesting properties, including low volumetric shrinkage or expansion upon curing [13], low water absorption, excellent resistance to chemicals and UV light $[14,15]$ and high thermal properties [16]. These properties are attributed to the unique $\mathrm{H}$-bonding structure found in these materials. In addition, benzoxazines can be polymerized without strong acid or base catalyst and does not release any by-products during polymerization $[17,18]$. They are polymerized via a thermally induced ring opening reaction to form a phenolic structure characterized by a Mannich base bridge $\left(\mathrm{CH}_{2^{-}}\right.$ $\mathrm{NR}-\mathrm{CH}_{2}$ ) instead of the methylene bridge associated with the traditional phenolic resins [19]. These characteristics enable this new candidate to have many technological applications.

The hybridization of polybenzoxazine with organoclay is a successful approach for obtaining high performance polybenzoxazines [20-22]. Agag et al prepared polybenzoxazine-clay nanocomposites from bisphenol-A / aniline type precursor (Ba) and organically modified montmorillonite (OMMT), showing that the $T_{g} s$ of the hybrid materials were higher than that of the pristine resin. In addition, the storage moduli of the hybrid materials were maintained up to higher temperatures suggesting the reinforcement attained by OMMT. Furthermore, the nanocomposites had a delayed decomposition temperatures when compared with pristine polybenzoxazine indicating the enhancement in the thermal stability [20, 21]. Recently, novel polybenzoxazine-clay hybrids were prepared by the in-situ polymerization of the B-a with aminolauric acid-modified mica [22]. The higher aspect ratio of mica gave hybrid with higher storage modulus over the whole temperature range than the neat polybenzoxazine and the thermal stability increased apparently by hybridization with mica corresponding to the mica content.

The current work represents apart of our ongoing studies on polybenzoxazine-clay hybrids. An easy processable and tough type of polybenzoxazine-clay hybrids has 
been prepared. The preparation and properties of these novel hybrids will be discussed.

\section{EXPERIMENTAL}

\subsection{Materials}

Bisphenol-A and dodecylamine were obtained from Kishida Co. Japan. Paraformaldehyde and Dioxane were obtained from Merck Co. Sodium montmorillonite (Na-MMT) with cation exchange capacity (CEC) of ca. 119 $\mathrm{mEq} / 100 \mathrm{~g}$ was supplied from Kunimine Industry Co. Japan, under trade name Kunipia-F. Aminolauric acid and N,N-dimethylstearylamine were purchased from Tokyo Kasei, Co. Japan. Tyramine hydrochloride was obtained from Aldrich Chemical Co. All chemicals were used without further purification.

\subsection{Preparation of Organoclays}

\subsubsection{Preparation of Tyramine-Modified Clay (Tyr-MMT)}

Sodium montmorillonite $(10 \mathrm{~g})$ was dispersed into $300 \mathrm{~mL}$ of hot water (about $80^{\circ} \mathrm{C}$ ) by using mechanical stirrer. Tyramine hydrochloride $(3.47 \mathrm{~g}, 20 \mathrm{mmol})$ dissolved in water $(20 \mathrm{~mL})$ was added portionwise into suspension montmorillonite under stirring at $80^{\circ} \mathrm{C}$ for $5 \mathrm{~h}$. The precipitate was collected by filtration, washed several times with hot water $80^{\circ} \mathrm{C}$ until no white precipitate of $\mathrm{AgCl}$ was formed by addition of $0.1 \mathrm{~N}$ $\mathrm{AgNo}_{3}$ to the filtrate. Finally, the precipitate was dried under vacuum at $80^{\circ} \mathrm{C}$ for $24 \mathrm{~h}$ to yield tyramine modified montmorillonite (Tyr-MMT). The resulted organoclay was sieved to get particles less than $63 \mu \mathrm{m}$.

\subsection{Preparation of 12-Aminolauric Acid-Modified Clay (ALA-MMT)}

ALA-MMT was prepared by applying the same method as Tyr-MMT using Na-MMT $(15 \mathrm{~g}),, \mathrm{HCl}(23.4 \mathrm{mmol}, 2.43 \mathrm{~g})$ and aminolauric acid $(23.4 \mathrm{mmol}, 5.03 \mathrm{~g})$. The resulted organoclay was sieved to get particles less than $63 \mu \mathrm{m}$.

\subsection{Preparation of $\mathrm{N}, \mathrm{N}$-dimethylstearylamine-Modified Clay (DMS- MMT)}

DMS-MMT was prepared from Na-MMT $(10 \mathrm{~g}),, \mathrm{HCl}(1.19 \mathrm{~m} \mathrm{~mol}, 0.045 \mathrm{~g})$ and $\mathrm{N}, \mathrm{N}-$ dimethylstearyl amine $(1.19 \mathrm{mmol}, 0.353 \mathrm{~g})$ in $30 \mathrm{ml}$ dist. The resulted organoclay was sieved to get particles less than $63 \mu \mathrm{m}$. 


\subsection{Preparation of Polybenzoxazine-Clay Hybrids}

Two methods were used for the preparation of the hybrids.

\section{A- Method I}

The following is a typical method used for preparation of Illa. Into $100 \mathrm{ml}$ flask, Tyr-MMT $(0.718 \mathrm{~g})$ was dispersed in dodecylamine $(40 \mathrm{mmol}, 7.41 \mathrm{~g})$ at $80^{\circ} \mathrm{C}$. Then, Bisphenol-A $(20 \mathrm{mmol}, 4.56 \mathrm{~g})$ and paraformaldehyde (80 mmol, $2.42 \mathrm{~g}$ ) were added. The mixture was heated for $2 \mathrm{~h}$ at $120^{\circ} \mathrm{C}$. After cooling a yellow viscous material was obtained.

The as-synthesized monomer-clay IIla was cast over glass plates after treating with dichlorodimethylsilane. The cast film was heated at $110^{\circ} \mathrm{C}$ for 4 $\mathrm{h}$ under vacuum to remove any entrapped air bubbles, followed by thermal gradual treatment at $100,150,200$, and $220^{\circ} \mathrm{C}$ for $1 \mathrm{~h}$ at each. The obtained hybrid films have wine color. Similarly, polybenzoxazine-clay hybrids containing different content of Tyr-MMT and DMS-MMT were prepared.

\section{B- Method $\Pi$}

Into $100 \mathrm{ml}$ flask, Tyr-MMT $(0.718 \mathrm{~g})$ was dispersed into dioxane $(20 \mathrm{ml})$ at room temperature for $2 \mathrm{~h}$. Bisphenol-A $(20 \mathrm{mmol}, 4.56 \mathrm{~g})$ was added to TyrMMT suspension at $80^{\circ} \mathrm{C}$, then dodecylamine $(40 \mathrm{mmol}, 7.41 \mathrm{~g})$ and paraformaldehyde $(80 \mathrm{mmol}, 2.42 \mathrm{~g})$ were added portionwise. The mixture was heated with stirring at $120^{\circ} \mathrm{C}$ for $2 \mathrm{~h}$. After cooling a yellow viscous material (la) in dioxane was obtained.

The as-synthesized monomer/clay (la) was dissolved in dioxane to lower the viscosity to enable casting in a film form. The solution was cast over glass plates after treating with dichlorodimethylsilane. The cast film was heated under vacuum at $110^{\circ} \mathrm{C}$ for $4 \mathrm{~h}$ to remove the solvent, followed by gradual thermal treatment at $100,150,200$, and $220^{\circ} \mathrm{C}$ for $1 \mathrm{~h}$ at each. The obtained hybrid films have wine color. Similarly, polybenzoxazine-clay hybrid containing different content of Tyr-MMT and ALA-MMT were prepared.

\subsection{Measurements}

Infrared (IR) was performed by Perkin Elemer -1430, in a wave number rang of $4000-400 \mathrm{~cm}^{-1}$. Differential scanning calorimetry (DSC) was carried out using a Rigaku calorimeter Thermo Plus 2 DSC8230 at a heating rate of $10^{\circ} \mathrm{C} / \mathrm{min}^{-1}$ under nitrogen atmosphere. Thermogravimetric analysis (TGA) was conducted on a Rigaku Thermo plus 2 TG 8120 analyzer at heating rate of $10^{\circ} \mathrm{C} / \mathrm{min}^{-1}$ under an argon atmosphere. The morphology of the composite was examined by Scanning Electron Microscopy (SEM) Joel JXA-840 equipped with an energy dispersive X-ray detector. The hardness was measured with a Vickers hardness measured used AKASHI AVK-A machine. Mechanical properties (tensile) of the samples were tested with an Instron mechanical tester [model DL-35/ LR5K plus (LLOYD)] at crosshead speed of 500 $\mathrm{mm} \mathrm{min}^{-1}$. the l-shaped specimen were prepared with $5 \mathrm{~cm}\left(5 \times 10^{-2}\right)$ in length, $1 \mathrm{~cm}$ $(1 \times 10-2)$ in width, and 330-450 $\mathrm{mm}\left(0.33-0.45 \times 10^{-2}\right)$ in thickness. For each datum point, five samples were tested, and the average value was recorded. 


\section{RESULTS AND DISCUSSION}

\subsection{Preparation of Benzoxazine-Clay Materials}

Preparation of organoclays (OMMT) is shown in Scheme 1, and their The XRD of NaMMT and organoclays (OMMTs) are shown in Fig. 1. The diffraction peaks of NaMMT lattice structure due to d-spacing was shifted to lower angels by the modification with tyramine (Tyr), aminolauric acid (ALA) and $\mathrm{N}, \mathrm{N}$ dimethylstearylamine (DMS) as intercalating agent. The original d-spacing of $\mathrm{Na}$ MMT (1.24 nm) increased to 1.52 and 1.83 and $1.97 \mathrm{~nm}$ with modification with Tyr, ALA, and DMS, respectively. This suggests that the interlayer spacing increased with increase the length of the intercalating agent.

The new method used for the preparation of polybenzoxazine-clay nanocomposites in this study is based on the in-situ formation of benzoxazine monomers in presence of organoclay in presence and absence of solvent solvent as show in Scheme 2. Benzoxazine-clay materials were prepared by the reaction of bisphenol-A, dodecylamine and paraformaldehyde in the presence of organoclay. IR spectra shown Fig. 2 mentined the absorption bands at $932 \mathrm{~cm}^{-1}$ (trisubistuted benzene), $1206 \mathrm{~cm}^{-1}$ (cyclic ether linkage), $1331 \mathrm{~cm}^{-1}\left(\mathrm{CH}_{2}\right.$ of benzoxazine ring), and $1491 \mathrm{~cm}^{-1}$ attributed to benzoxazine structure. The absorptions at 558 and $1024 \mathrm{~cm}^{-1}$ are due to $\mathrm{Si}-\mathrm{O}$ in the frame work structure of MMT layers [21].

The cure behavior of benzoxazine in the presence of organoclays was studied by DSC. Fig 3 \& 4 show the DSC of the pristine B-dod with lb with Illb for comparison. The neat benzoxazine monomer (B-dod) has an exotherm with maximum at $255^{\circ} \mathrm{C}$ while for $\mathrm{Ib}$ and IIIb an exotherm max. were observed at 229 and $219^{\circ} \mathrm{C}$ respectively. The shift of the cure exotherm to lower temperature for both $\mathrm{lb}$ and Illb than the neat monomer is due to the catalytic effect of the acidic onium protons inside the clay galleries on the ring opening polymerization of benzoxazines [21].

For monomer-clay materials (Ib) which was prepared using solventless method, the exotherm was shifted to lower temperature than that of solvent method (IIlb). This suggested that the intercalation of monomer into the clay galleries is high in the absence of solvent, leading to the higher adhesion with clay surface and hence the higher of catalytic activity by clay surfaces. The increase of the clay content, the shift of the exotherm to lower temperature as shown in Fig 4.

The polymerization of benzoxazine-clay materials was followed by IR and DSC analysis. Fig. 5 shows the DSC cure of poly( IIIb), the disappearance of exothermic peak due to the ring opening polymerization suggests the completion of the polymerization of the hybrid. Further cure conformation of IIlb was done by IR spectra. Fig 7. showed the decreased of the absorption bands at $920,1492 \mathrm{~cm}^{-1}$ (trisubistuted benzene), $1240 \mathrm{~cm}^{-1}$ (ether linkage) and $1330 \mathrm{~cm}^{-1}\left(\mathrm{CH}_{2}\right.$ of benzoxazine ring). While the absorption for tetra-substituted mode at $1491 \mathrm{~cm}^{-1}$ increased. The absorption at 558 and $1034 \mathrm{~cm}^{-1}$ present in all stages is attributed to Si-O in MMT layers [21]. 


\subsection{Morphology of Polybenzoxazine Clay Nanocomposites}

The increase and collapse of the interlayer spacing of the lattice structure of the layered silicates is often monitored by XRD. Fig 7 shows Tyr-MMT, la, Ib, Ic and Fig 8 show the XRD of the ALA-MMT, Ila, Ilb, and Ilc. The absence of reflections in the XRD patterns of the hybrids indicating that the lattice structure of OMMT was collapsed due to the polymerized of polybenzoxazine into the gallery of organoclay.

Fig. 9, 10 show the B-dod/Tyr-MMT and B-dod/DMS hybrid which were prepared by solventless. XRD show the absence of reflection in the XRD patterns of the hybrids indicates that the lattice structure of clay as a layered silicate was collapsed and the silicate sheets are homogenously dispersed into the polybenzoxazine matrix. This suggests the disorder and loss of structure registry of the MMT layers. Thus, the clay tactoids are considered to be exfoliated and the $0.69 \mathrm{~nm}$ thick MMT layers dispersed at the molecular level into the matrix. This means that the exfoliation has occurred that the clay is disordered.

\subsection{Properties of Polybenzoxazine-Clay Nanocomposites}

The inclusion of organoclay into polybenzoxazine matrix increased the hardness. The Vickers hardness was measured to evaluate the influence of the inclusion of the clay into the polybenzoxazine Fig 12 shows the hardness of the nanocomposites increased tediously in proportion to the clay content. In the polybenzoxazine / TyrMMT the hardness is more than the polybenzoxazine / ALA-MMT due to the possibility of interaction of phenolic moties of tyramine in the reaction network structure of polybenzoxazine.

Fig 13 shows the hardness of IIIa, IIIb, and IIIc with IIIla, IIIIb, and IIIIC nanocomposites. In the Tyr-MMT / polybenzoxazine the hardness is more than the DMS-MMT / polybenzoxazine due to aliphatic part of the modifier (DMS) which has low hardness due to mobility of aliphatic chain.

The hardness of hybrid materials which prepared by in-situ solventless has high hardness value than the hybrid prepared by in-situ solvent method. Fig 14 shows the gray bars instate of the la, Ib, Ic and the black bars instate of the IIIa, IIIb and IIIc with the neat resin B-dod. For the B-dod, $\mathrm{lb}$ and IIIb the hardness value was 0.24 , 0.33 and $0.85 \mathrm{GPa}$ respectively. Thus investigated that, the in-situ formed of benzoxazine in the presence of clay in the absence of solvent than in the presence of it increased the formation into the gallery of clay, this suggest the increased of network structure of polybenzoxazine increased the hardness of the hybrid was more effective and easily processability method than the other method.

The tensile properties of B-dod/Tyr-MMT and B-dod/DMS-MMT were examined, and the results are summarized in Table $1 \& 2$, as shown in Fig 15. For B-dod/Tyr-MMT (III) series the tensile properties changed with the incorporation of Tyr-MMT. As the content of clay modified increase, the tensile modulus also increase, the neat resin (B-dod) was 6.9 MPa while the IIla and IIIb were 7.34 and $8.46 \mathrm{MPa}$. However, the elongation at break decreased with increase of Tyr-MMT content. For B-dod/DMSMMT (IIII) series the tensile decreased and the elongation increased. There was a 
tendency for the type of the modifier of clay, where in the IIII series the long aliphatic chain has high flexibility and low $\mathrm{T}_{\mathrm{g}}$ so they have high elongation and low modulus. While the series of Tyr-MMT the aromatic manner have high $\mathrm{T}_{g}$, thus have high modulus and low elongation.

Thermogravimetric analysis was used to investigate the thermal stability of the hybrid materials under argon and air atmosphere. The thermal stability of polymer composites is generally estimated from the weight loss upon heating which results in the formation of volatile products. The improved thermal stability in polymer nanocomposites is due to the clay platelets which hinder the diffusion of volatiles and assist the formation of char after thermal decomposition. The TGA. of la and Ib under air atmosphere shows in Fig 16. The hybrids has two decomposition stages, the first one was due to the decomposition of aliphatic parts of amine. This stage started at $226^{\circ} \mathrm{C}$ and continued up to $370^{\circ} \mathrm{C}$. The other stage was due to the weight loss decomposition of the rest of the polymer. However the T5 and T10 of la and Ib were $263,295^{\circ} \mathrm{C}$ and $294,325^{\circ} \mathrm{C}$ respectively.

Fig. 17 shows the TGA of neat resin (B-dod), Ib and Ic under argon. The T5 and $\mathrm{T} 10$ in $\mathrm{lb}$ was $298 \& 318^{\circ} \mathrm{C}$ respectively however in Ic was $294 \& 326^{\circ} \mathrm{C}$ respectively and the weight residue increased from the neat resin $12 \%$ to 30 and $39 \%$ in $\mathrm{lb}$ and $\mathrm{Ic}$ respectively.

Fig. 18. shows the TGA of poly (IIla, IIlb, IIIc) and Fig 19 shows TGA for poly (IIIla, $\mathrm{IIIIb}$, IIIIC). For poly (IIla) and poly (IIIla) it was found that there was no significant difference on the initial decomposition behavior of the hybrid. For the neat resin (Bdod), poly(IIIb) and poly(IIIlb) the char yield was $12 \%, 26 \%$ and $23 \%$ respectively. The enhancement in chair yield and thermal stability of all the hybrid samples was suggested. This enhancement in thermal stability is due to the barrier effect of the dispersed layered silicates which act as barriers to minimize the permeability of the oxygen into the bulk of the material $[20,23]$. As a result, the hybrid showed a delayed decomposition behavior than the neat resin. 


\section{CONCLUSION}

One shot process was used to prepare series of novel nanocomposites by the inclusion of different organoclay into benzoxazine matrix to obtain polybenzoxazineclay hybrids. XRD indicated that the exfoliation of organoclay into benzoxazine matrix was achieved with organoclay loading high content such as 20 wt.\%. The presence of benzoxazine in the organoclay disturbs the delamination of clay layer. Hardness and tensile properties of the hybrid thermosettes were achieved by the inclusion of clay content. Thermal stability was enhancement by the inclusion of organoclay. This improvement in the properties is not only related to the clay content, but also the manner of clay dispersion in polybenzoxazine matrix and the preparation method also.

\section{REFERENCE}

[1] LeBaron, P. C., Wang, Z., Pinnavaia T., J. Appl. Clay. Sci., 15, 11, (1999).

[2] Vaia, R. A., Price, G., Ruth, P. N., Nguyen, H. T., Lichtenhan, J., Appl. Clay. Sci., 15, 67, (1999).

[3] Biswas, M., Sinha, R. S., Adv. Polym. Sci.,155, 167, (2001).

[4] Giannelis, E. P., Appl. Organomet. Chem., 12, 675,(1998).

[5] Messersmith, P. B., Giannelis E. P., J Polym. Sci., Part A: Polym. Chem., 33, 1047, (1995).

[6] Yano, K., Usuki, A., Okada, A., Kurauchi, T., Kamigaito, O., J Polym. Sci, Part A: Polym. Chem., 31, 2493, (1993).

[7] Kojima, Y., Usuki, A., Kawasumi, M., Fukushima, Y., Okada, A., Kurauchi, T., Kamigaito, O., J Mater. Res., 8, 1179, (1993).

[8] Bourbigot, S., LeBras, M., Dabrowski, F., Gilman, J. W., Kashiwagi, T., Fire Mater., 24, 201, (2000).

[9] Gilman, J. W., Jackson, C. L., Morgan, A. B., Harris, J. R., Manias, E., Giannelis, E. P., Wuthenow, M., Hilton, D., Phillips, S. H., Chem. Mater., 12, 1866, (2000).

[10] Sinha, R. S., Yamada, K., Okamoto, M., Ueda, K., Nano. Lett. 2, 1093, (2002).

[11] Clois, E. P., Gary W. B., J. Mater. Sci., ( 2006).

[12] Ishida, H., Low, H.Y., Macromolecules, 30, 1099, (1997).

[13] Kim, H. D., Ishida, H., J. Appl. Polym. Sci., 79, 1207, (2001).

[14] Macko, J. A., Ishida, H., J. Polym. Sci. B: Polym. Phys., 38, 2687, (2000).

[15] Agag, T., Takeichi, T., Macromolecules, 34, 7257, (2001).

[16] Ishida, H., Allen, D., Polym. 37, 4487, (1996).

[17] Ishida, H., Allen, D.J., J. Polym. Sci. B: Polym. Phys., 3, 1019, (1996).

[18] Dunkers, J., Ishida, H., Spectrochim. Acta., 51, 850, (1995).

[19] Agag, T., Takeichi, T., Polymer, 41, 7083, (2000).

[20] Takeichi, T., Zeidam, R., Agag, T., Polymer, 43, 45, (2002).

[21] Agag, T., Taepaisitphongse, V., Takeichi, T., Polym. Compos, 28, 680, (2007).

[22] Starr, B., Burts, E., Upson, J., Riffle, J., Polymer, 42, 8727, (2001).

[23] Agag, T., Takeichi, T., High Perform Polym., 14, 115, (2002). 


\section{Figure Caption}

Scheme 1 Preparation of organoclays

Scheme 2 Preparation of polybenzoxazine (bisphenol-A dodecylamine)/Tyr-MMT

Figure 1. XRD of Na-MMT and various organoclay (OMMTs

$\begin{array}{ll}\text { Figure 2. } & \text { derivatives): DMS-MMT, } \\ \text { IR Spectra of B-dod \& IIIb }\end{array}$

Figure 3. DSC of B-dod, Ib and IIIb after curing temperatures

Figure 4. DSC of la, Ib, Ic after curing temperatures

Figure 5. DSC of IIIb and poly IIIb after curing

Figure 6. IR Spectra of IIIb \& Poly(IIIb)

Figure 7. XRD of Tyr-MMT,poly la, Ib and Ic

Figure 8. XRD of ALA-MMT, poly Ila, Ilb and IIc

Figure 9. XRD of Tyr-MMT, poly IIla, IIIb and IIIc

Figure 10. XRD of DMS-MMT,poly IIIla, IIIIb and IIIIC

Figure 11. Hardness of poly B-dod, la, lb, Ic by black color and B-dod, Ila, Ilb, Ilc by gray color

Figure 12. Tensile properties of poly B-dod, IIIa, IIIb, IIIc \& IIIla, IIIIb, IIIIC

Figure 13 Hardness of poly B-dod, IIla, IIIb, IIIc by black color and Bdod, IIIla, IIIlb, IIIlc by gray color

Figure 14 Hardness of poly B-dod, la, Ib, lc by black color \& IIIa, IIIb, Illc by gray

Figure 15. TGA under air of poly la\& lb

Figure 16. TGA Ilc under air and Ilc under argon

Figure 17. TGA of polyB-dod, Ib\& Ic

Figure 18. TGA ofpoly B-dod, IIla, IIIb \& IIIC

Figure 19. TGA of B-dod, IIIla, IIIIb \& IIIIC 


\begin{tabular}{|c|c|c|c|c|c|c|}
\hline \multirow{3}{*}{ Code } & \multicolumn{5}{|c|}{ Composition } & \multirow[t]{3}{*}{ Condition } \\
\hline & \multicolumn{2}{|c|}{ Clay } & \multirow{2}{*}{$\begin{array}{l}\text { Bisphenol- } \\
\text { A (mml, g) }\end{array}$} & \multirow{2}{*}{$\begin{array}{l}\text { Dodecyl } \\
\text { amine } \\
(\mathrm{mml}, \mathrm{g})\end{array}$} & \multirow{2}{*}{$\begin{array}{c}\text { Paraformaldeh } \\
\text { yde (mml, g) }\end{array}$} & \\
\hline & Type & g, wt & & & & \\
\hline B-dod & 00 & 00 & $20,4.56$ & $40,7.4$ & $80,2.4$ & Solventless \\
\hline la & Tyr-MMT & $0.75,5 \%$ & $20,4.56$ & $40,7.4$ & $80,2.4$ & Solvent \\
\hline $\mathrm{Ib}$ & Tyr-MMT & $1.59,10 \%$ & $20,4.56$ & $40,7.4$ & $80,2.4$ & Solvent \\
\hline Ic & Tyr-MMT & $3.59,20 \%$ & $20,4.56$ & $40,7.4$ & $80,2.4$ & Solvent \\
\hline $\mathrm{Ila}$ & ALA-MMT & $0.75,5 \%$ & $20,4.56$ & $40,7.4$ & $80,2.4$ & Solvent \\
\hline $\mathrm{Ilb}$ & ALA-MMT & $1.59,10 \%$ & $20,4.56$ & $40,7.4$ & $80,2.4$ & Solvent \\
\hline IIC & ALA-MMT & $3.59,20 \%$ & $20,4.56$ & $40,7.4$ & $80,2.4$ & Solvent \\
\hline IIIa & Tyr-MMT & $0.75,5 \%$ & $20,4.56$ & $40,7.4$ & $80,2.4$ & Solventless \\
\hline $\mathrm{IIIb}$ & Tyr-MMT & $1.59,10 \%$ & $20,4.56$ & $40,7.4$ & $80,2.4$ & Solventless \\
\hline IIIC & Tyr-MMT & $3.59,20 \%$ & $20,4.56$ & $40,7.4$ & $80,2.4$ & Solventless \\
\hline IIIIa & DMS-MMT & $0.75,5 \%$ & $20,4.56$ & $40,7.4$ & $80,2.4$ & Solventless \\
\hline $\mathrm{IIIIb}$ & DMS-MMT & $1.59,10 \%$ & $20,4.56$ & $40,7.4$ & $80,2.4$ & Solventless \\
\hline IIIIC & DMS-MMT & $3.59,20 \%$ & $20,4.56$ & $40,7.4$ & $80,2.4$ & Solventless \\
\hline
\end{tabular}


Table of Tyr-B-dod

\begin{tabular}{cccc}
\hline Code & Clay content \% & $\begin{array}{c}\text { E modules at } \\
\text { Break (MPa) }\end{array}$ & $\begin{array}{c}\text { Elongation at } \\
\text { Break \% }\end{array}$ \\
\hline B-dod & 0 & 6.9 & 2 \\
IIIa & 3 & 7.34 & 1.8 \\
IIIb & 5 & 8.46 & 1.4 \\
IIIc & 10 & 11.23 & 1.1 \\
\hline
\end{tabular}

Table of DMS-B-dod

\begin{tabular}{cccc}
\hline Code & Clay content \% & $\begin{array}{c}\text { E modules at } \\
\text { Break (MPa) }\end{array}$ & $\begin{array}{c}\text { Elongation at } \\
\text { Break \% }\end{array}$ \\
B-dod & 0 & 6.9 & 2 \\
IIIla & 3 & 7.12 & 2.2 \\
IIIIb & 7 & 7.59 & 2.4 \\
IIIlC & 10 & 9.6 & 2.5 \\
\hline
\end{tabular}




$$
\begin{aligned}
& \mathrm{H}_{3} \mathrm{C} \quad \mathrm{CH}_{3} \quad \mathrm{H}_{3} \mathrm{C}_{+} \mathrm{Cl}^{-} \quad \mathrm{H}_{3} \mathrm{C}_{+} \mathbf{R}
\end{aligned}
$$

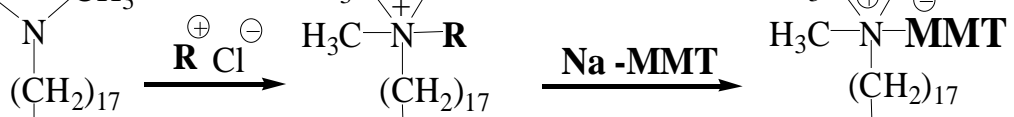

$$
\begin{aligned}
& \mathrm{CH}_{3} \quad \mathrm{CH}_{3} \quad \mathrm{CH}_{3} \\
& \mathbf{R}:-\mathrm{H}(\mathrm{Vc}) \quad, \quad\left(\mathrm{CH}_{2}\right)_{11} \mathrm{COOH}(\mathrm{Vb}) \text { or }\left(\mathrm{H}_{2} \mathrm{C}\right)_{2}-\mathrm{OH}(\mathrm{Va})
\end{aligned}
$$

\section{OMMT}

\section{Scheme 1.}

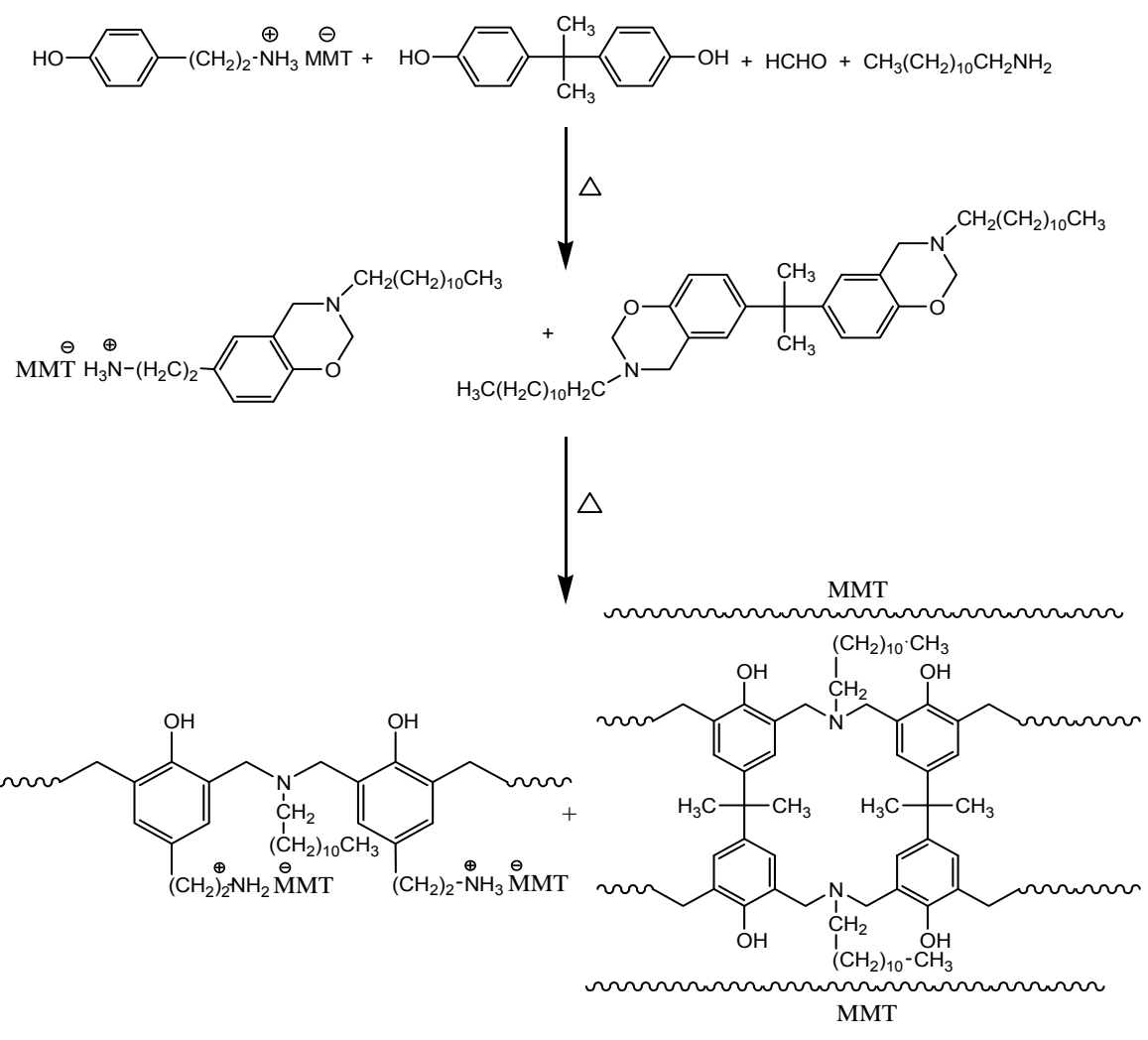

Tyr-MMT-B-dod Hybrid

Scheme 2. 


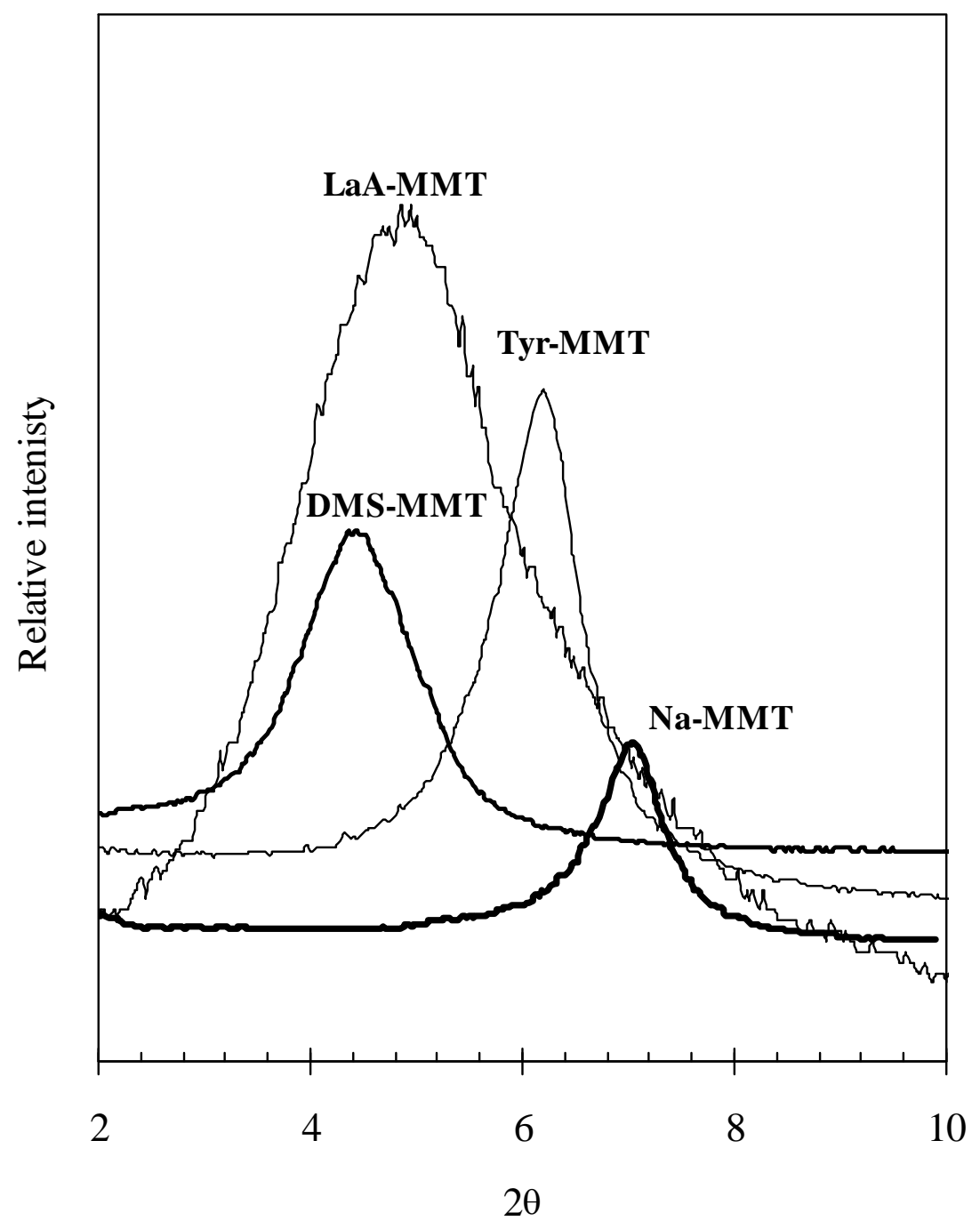

Figure 1 


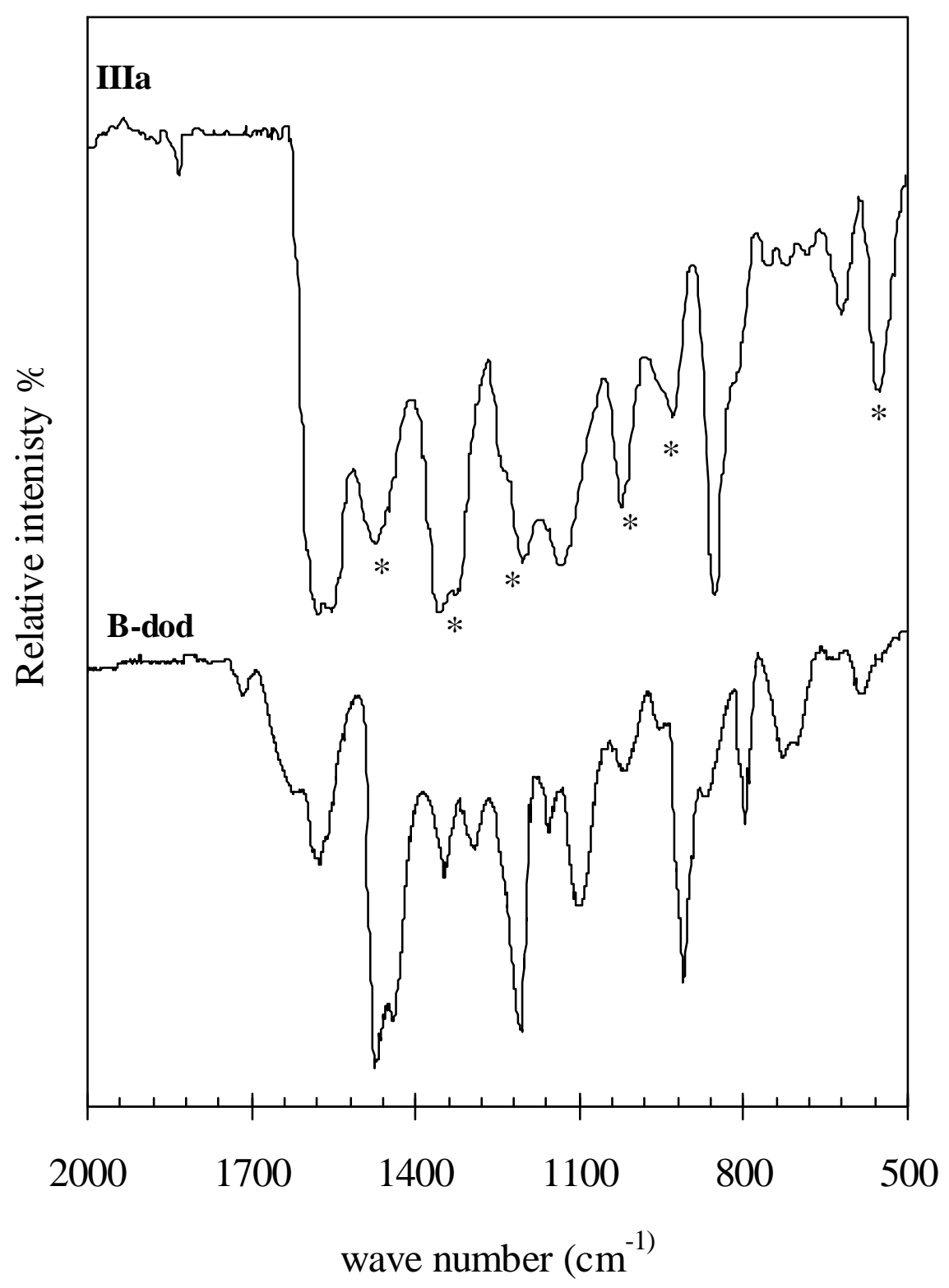

Figure 2 


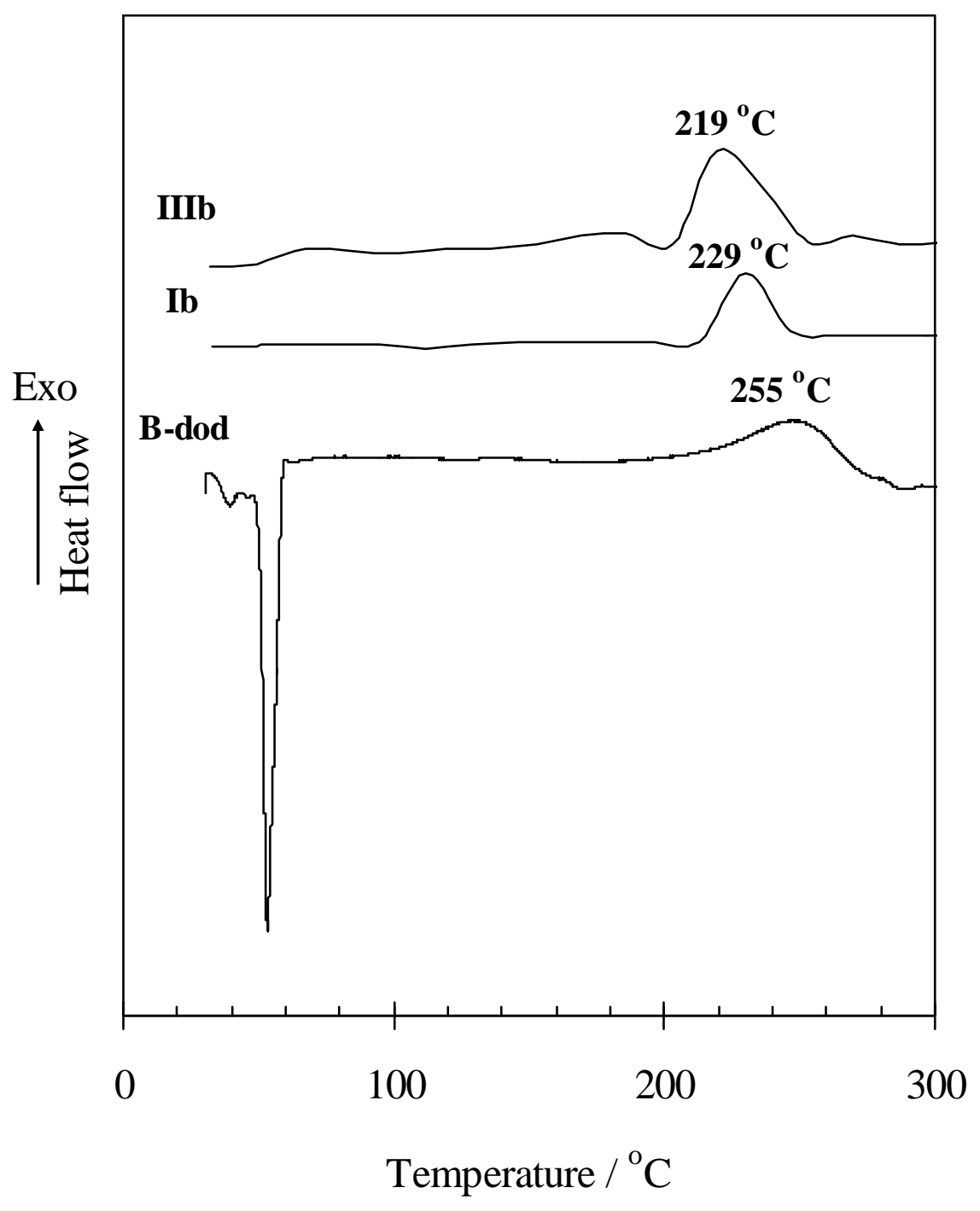

Figure 3 


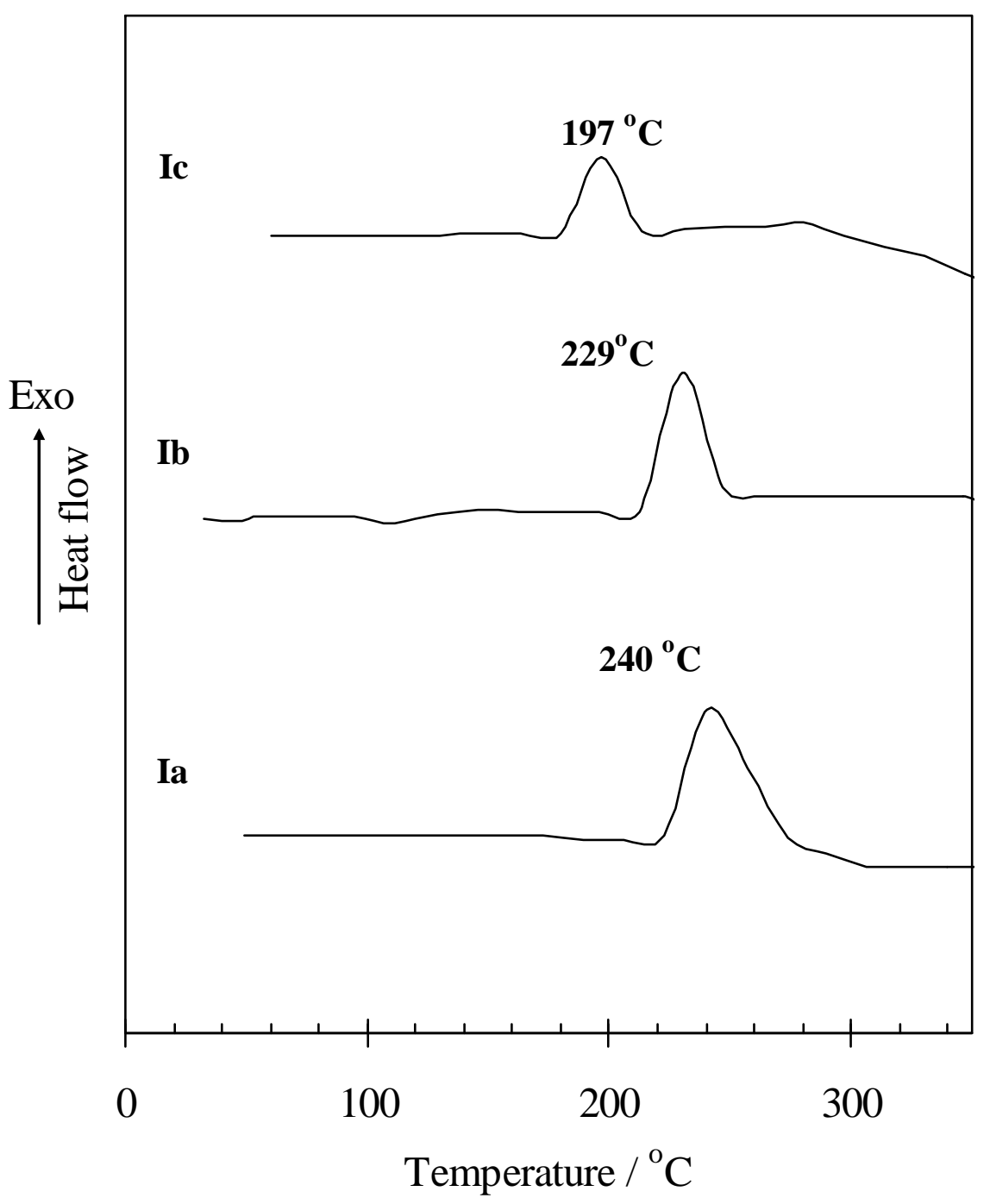

Figure 4 


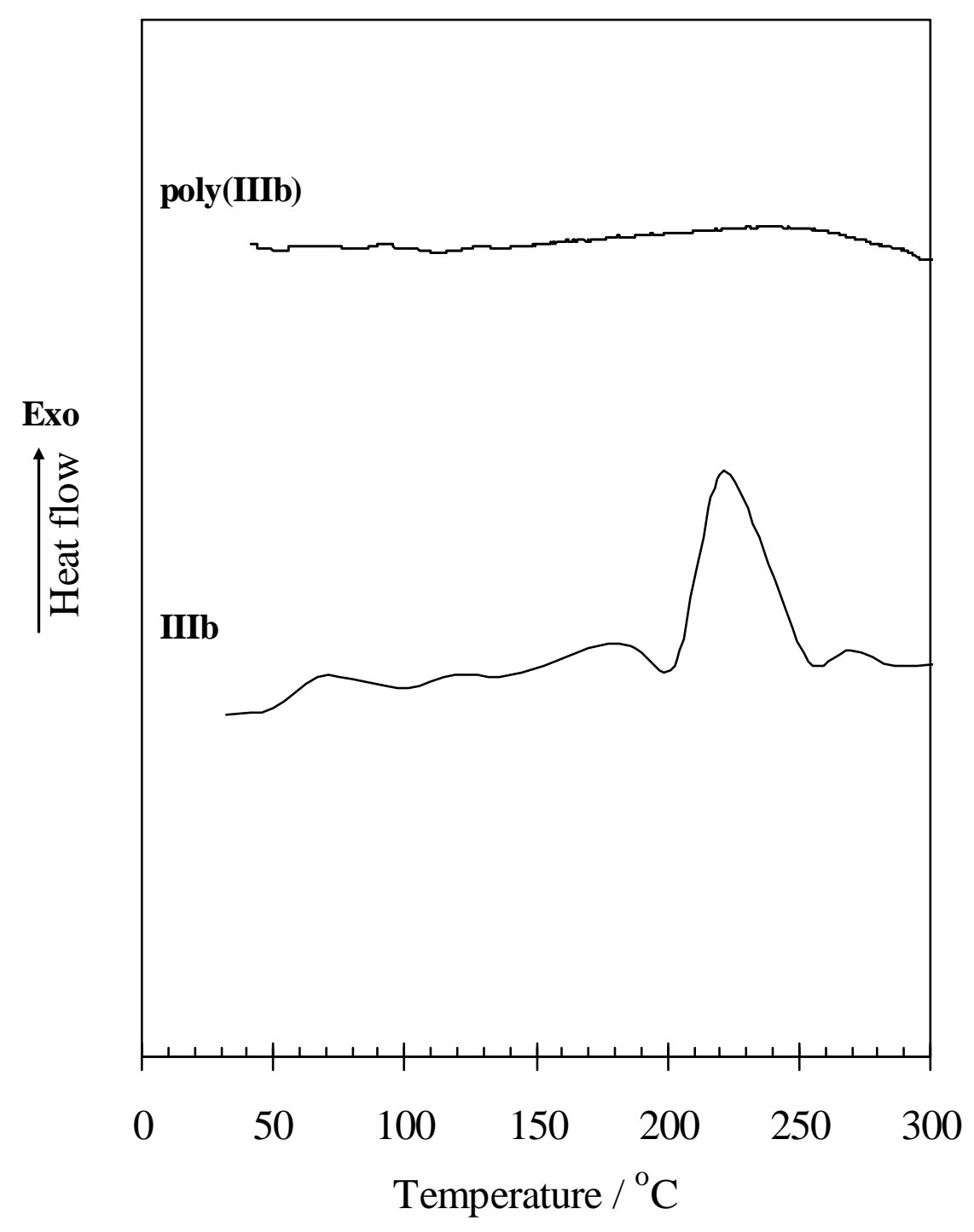

Figure 5 


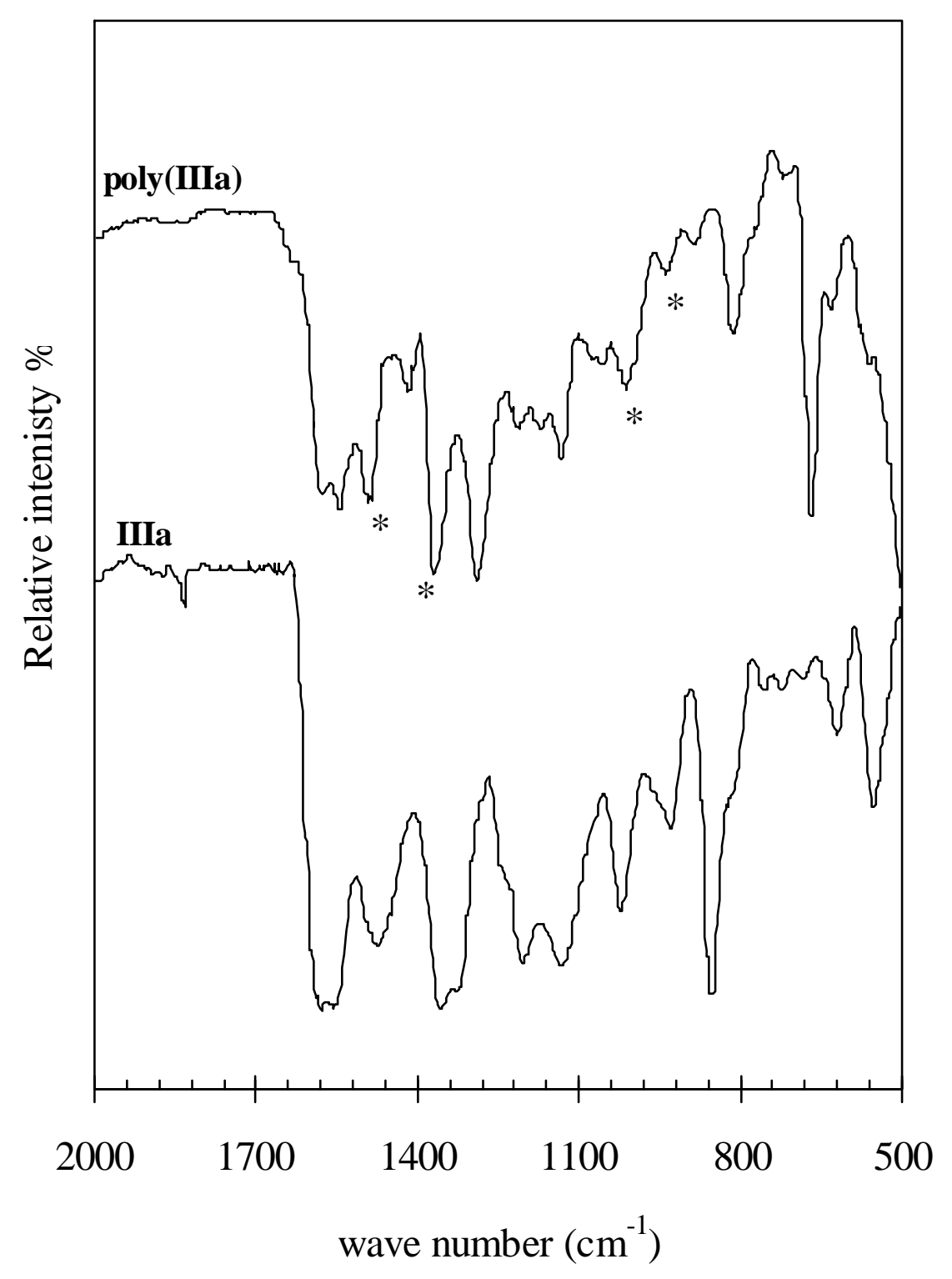

Figure 6 


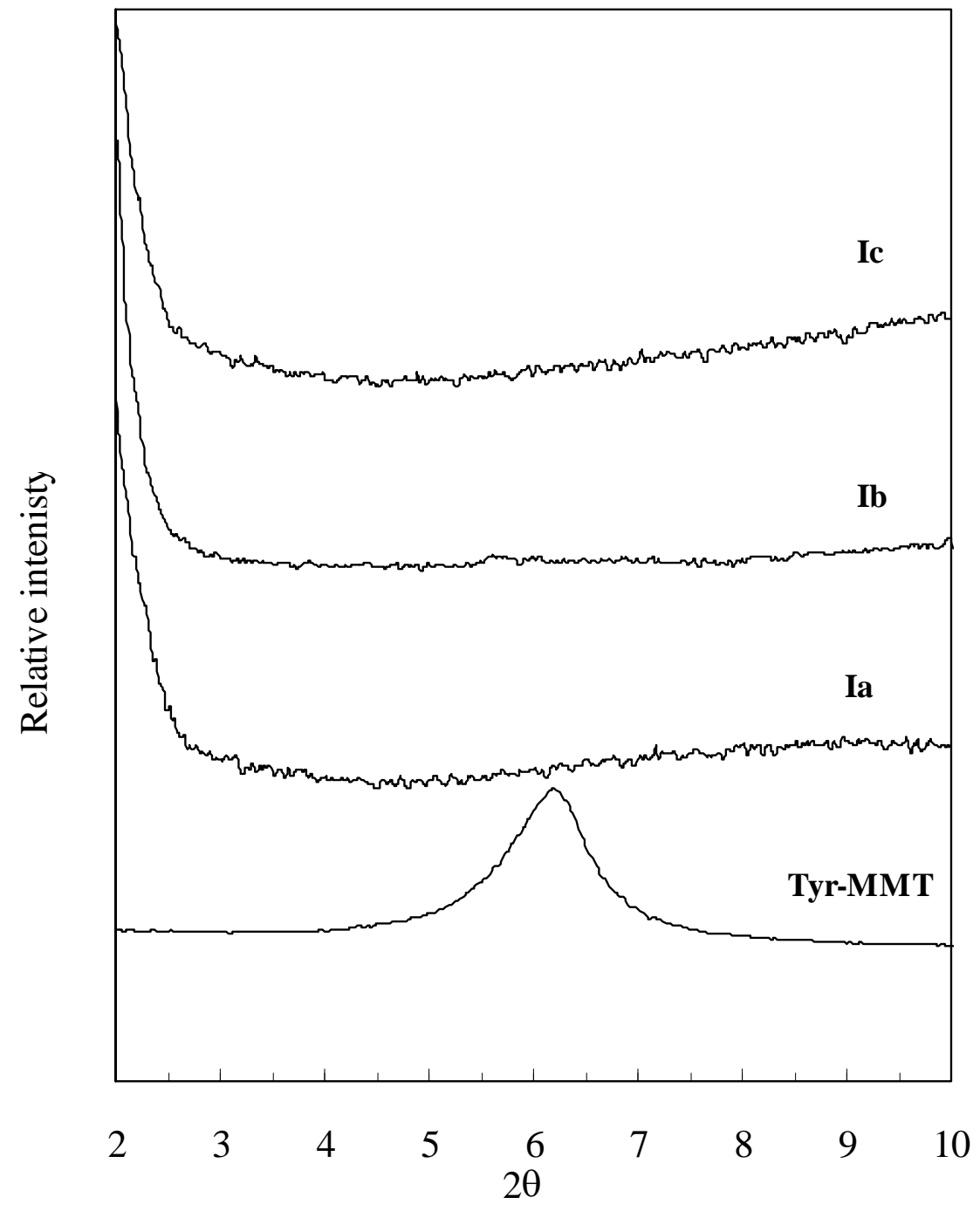

Figure 7 


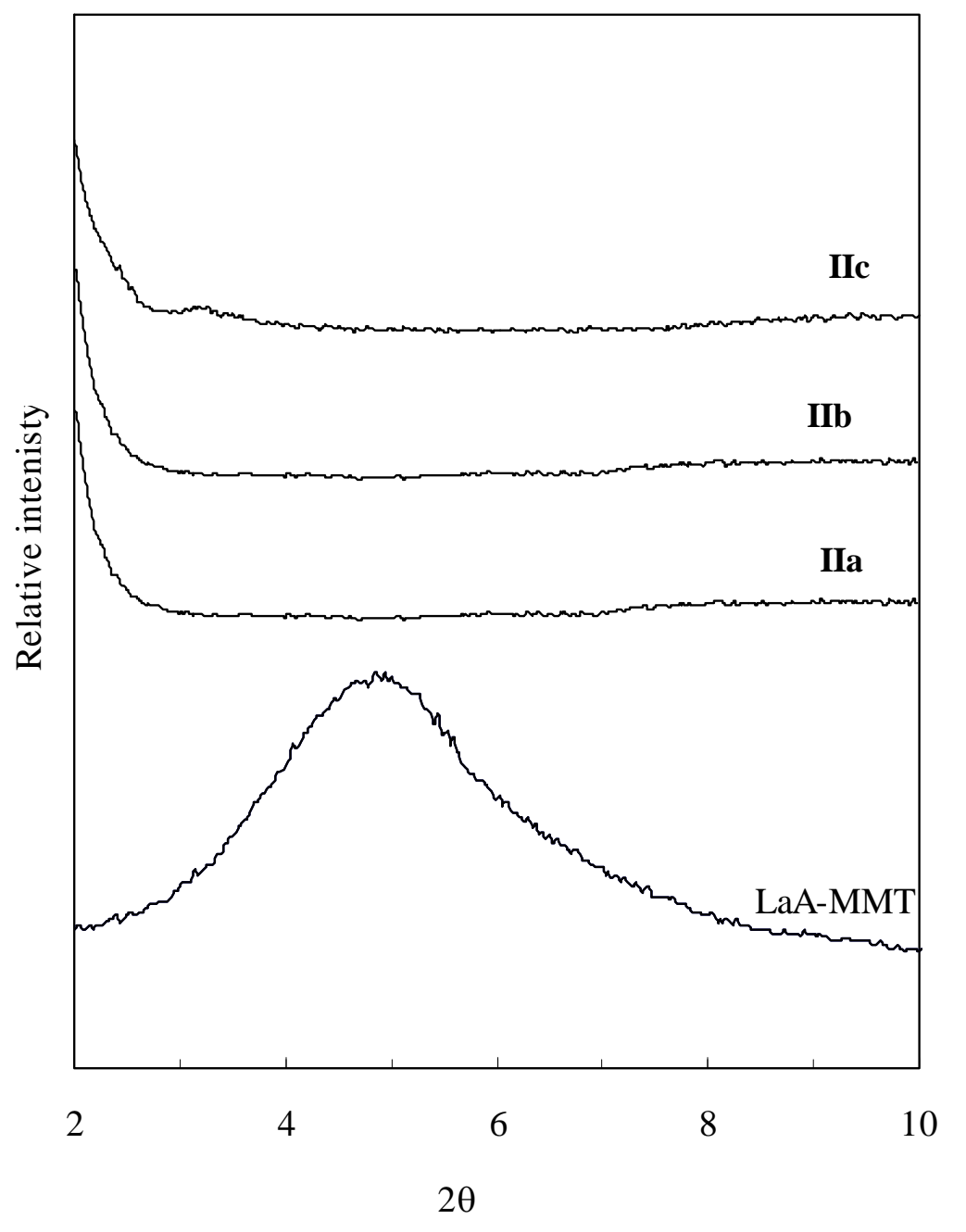

Figure 8 


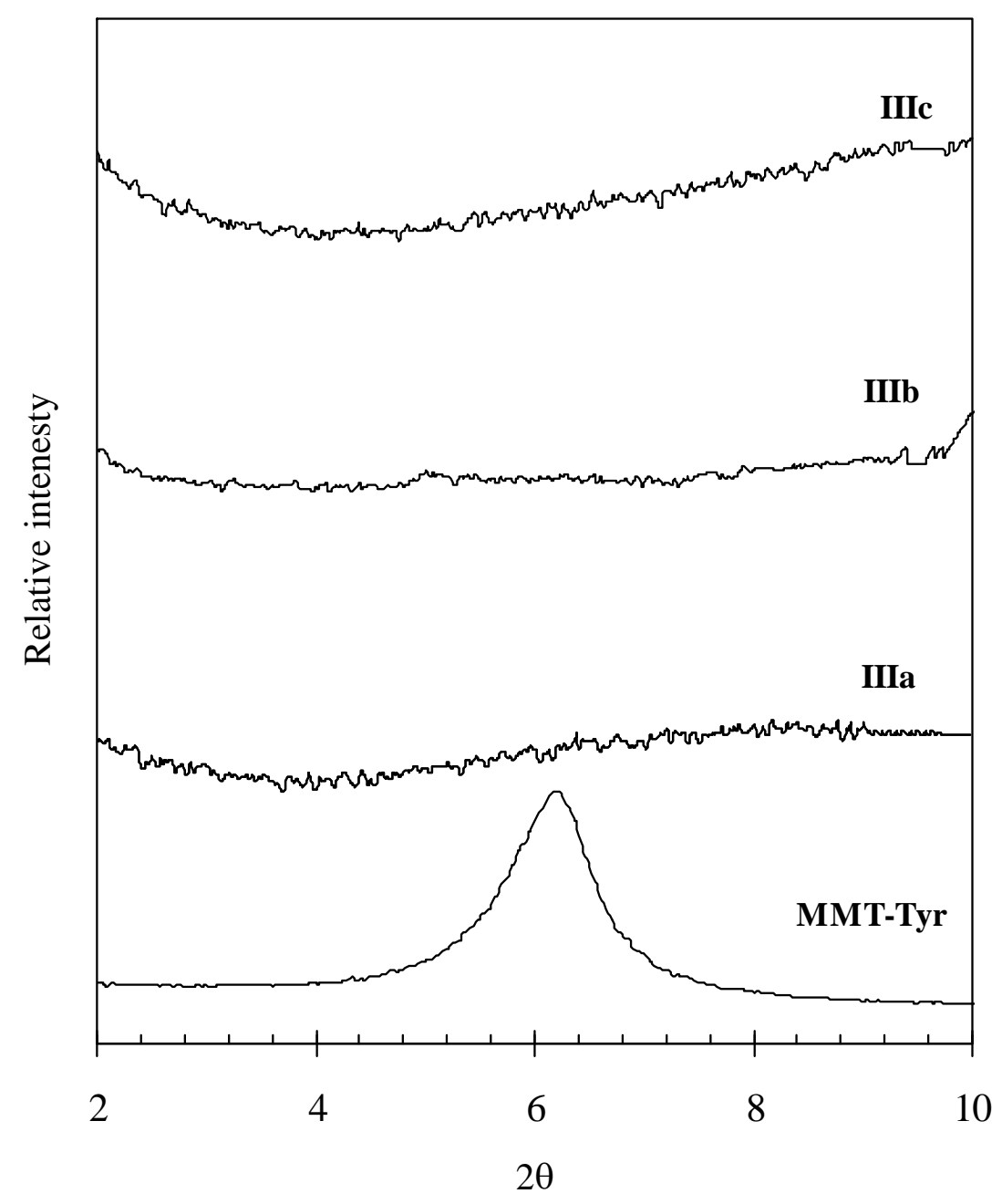

Figure 9 


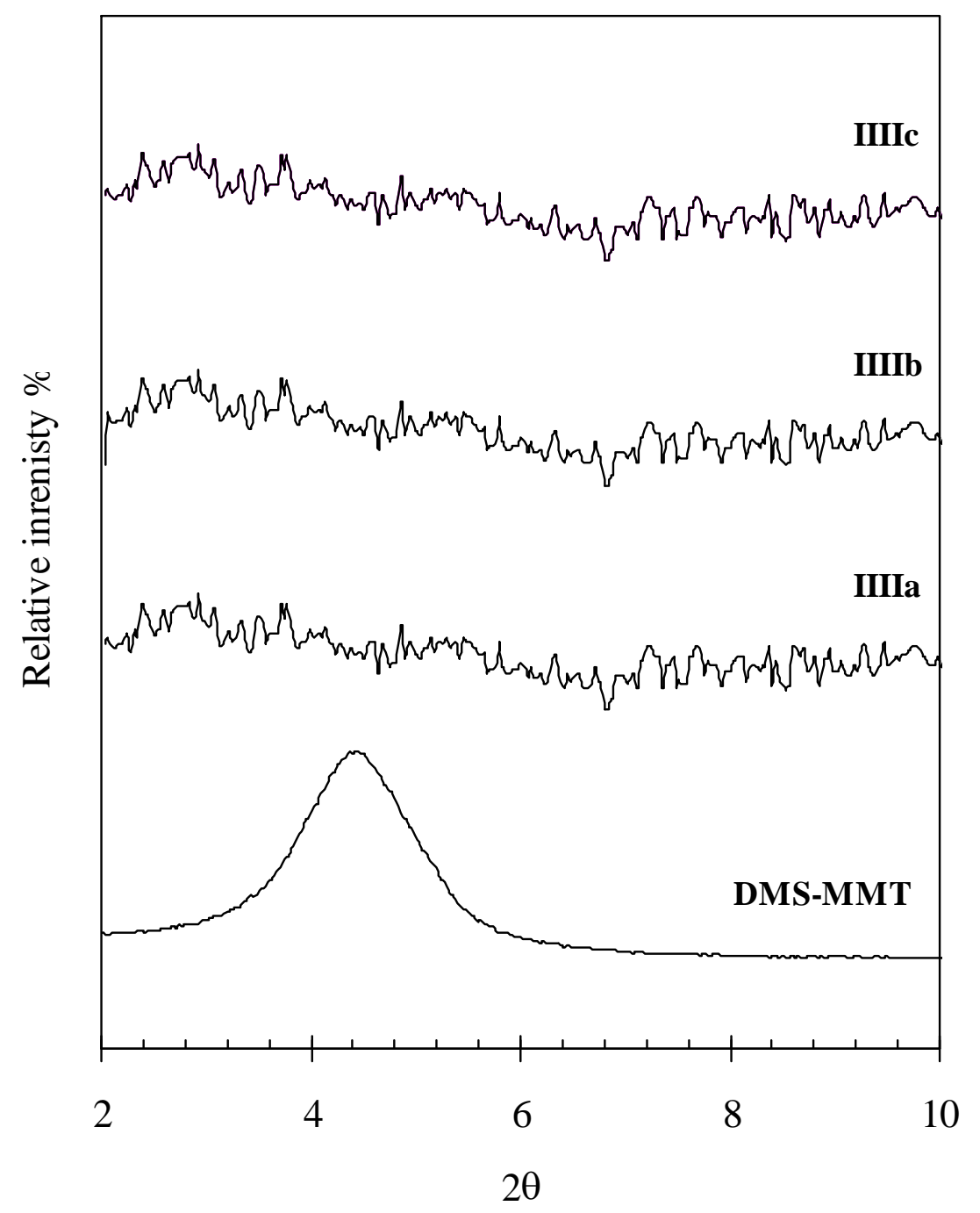

Figure 10 


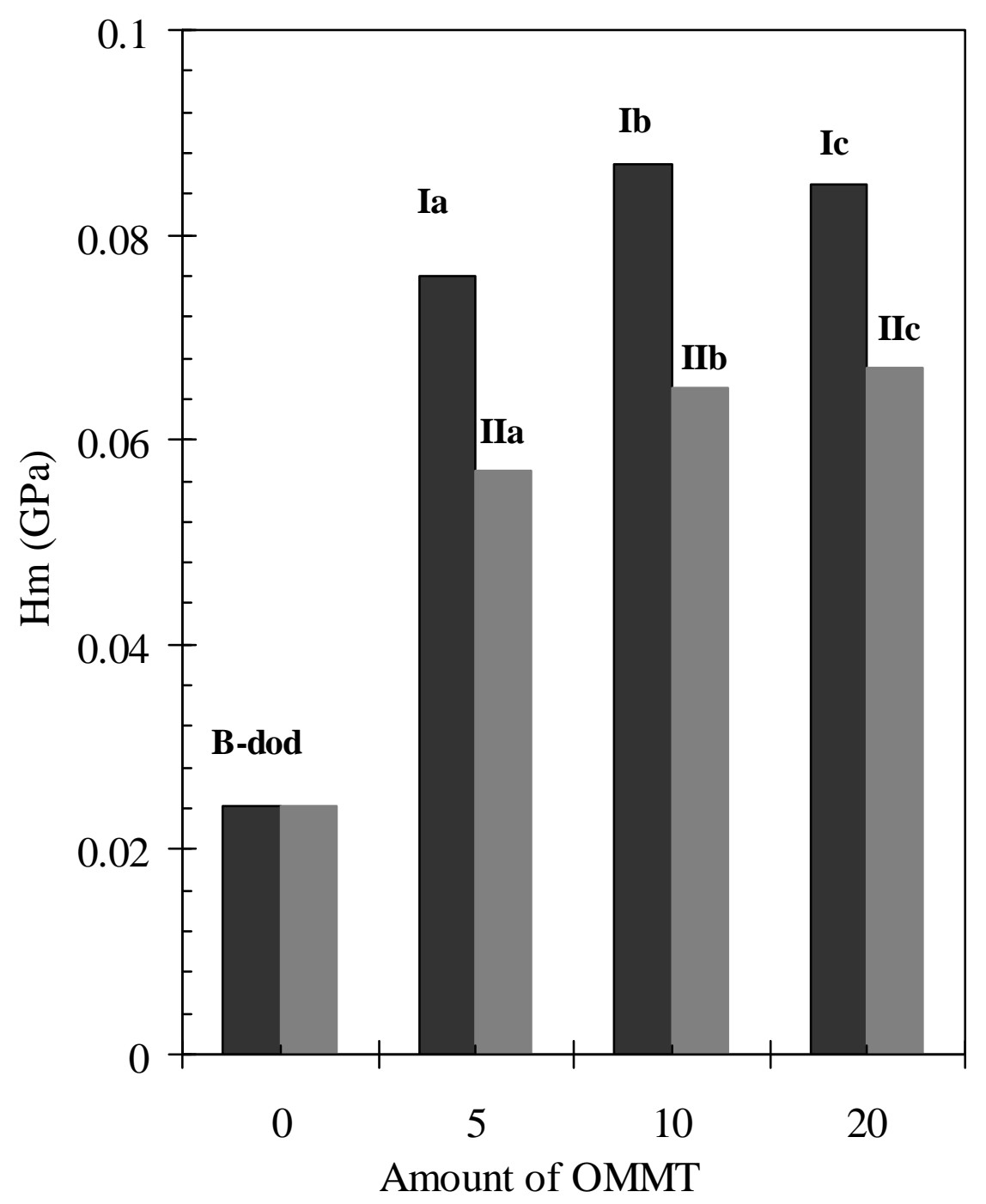

Figure 11 


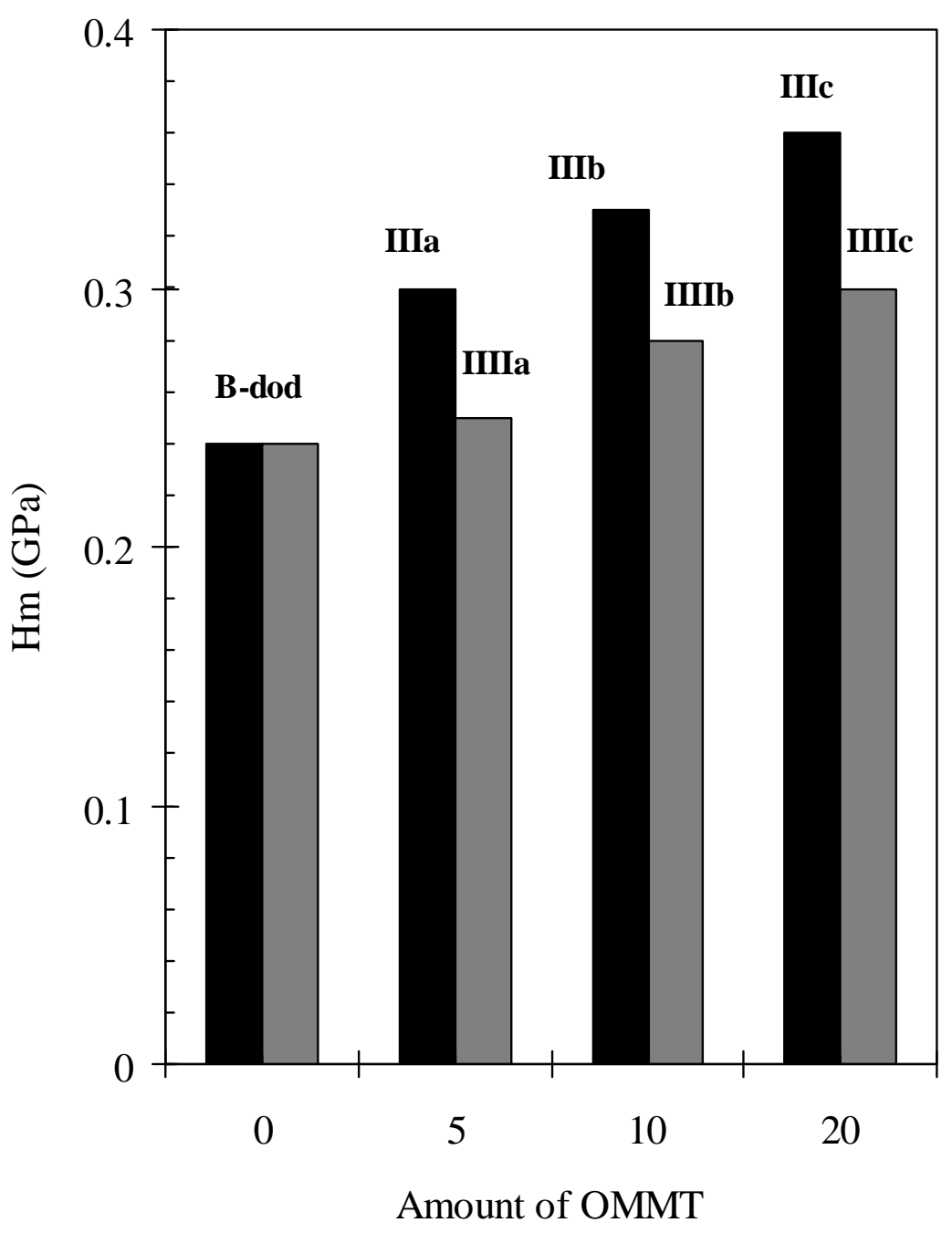

Figure 12 


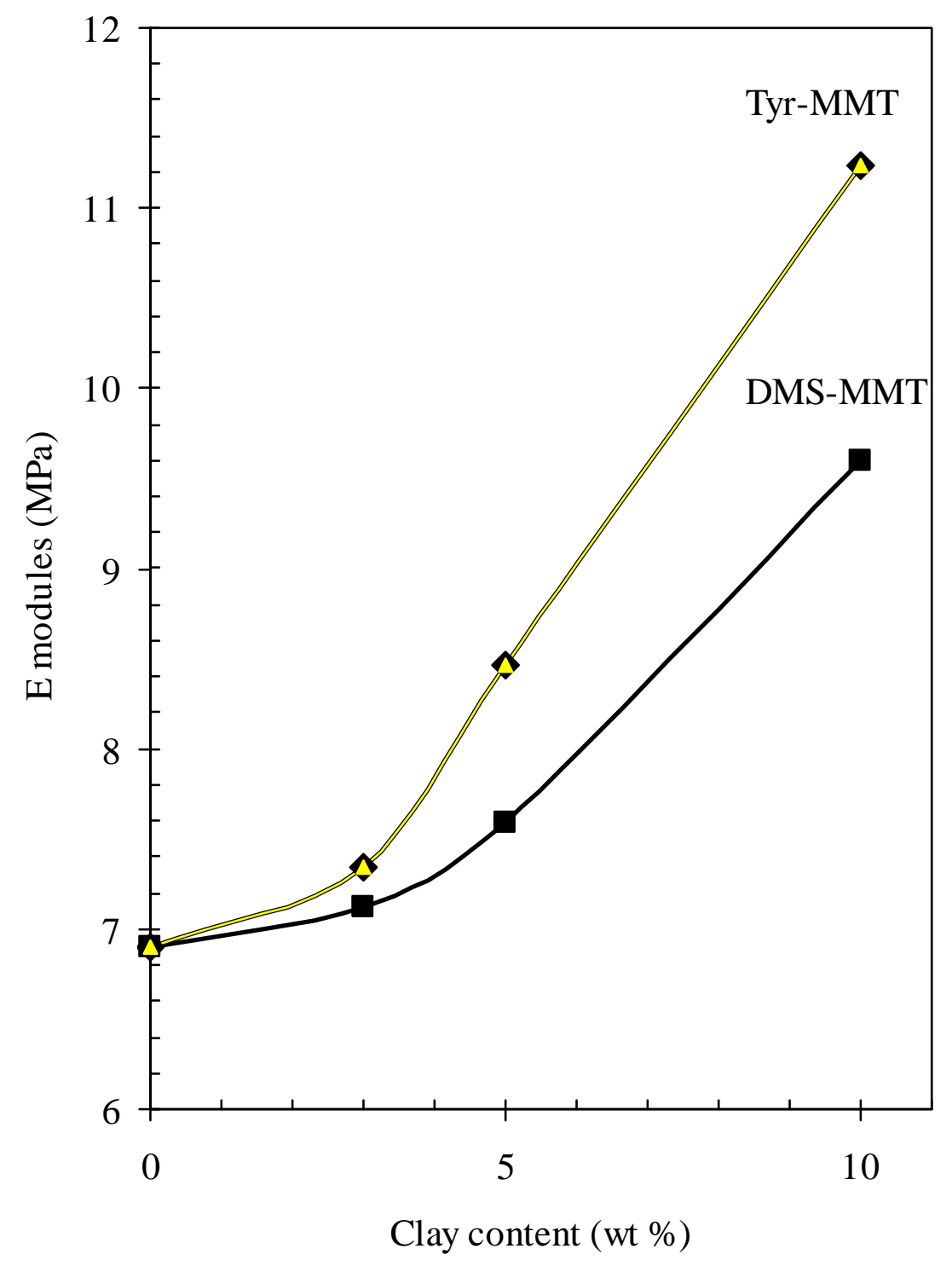

Figure 13 


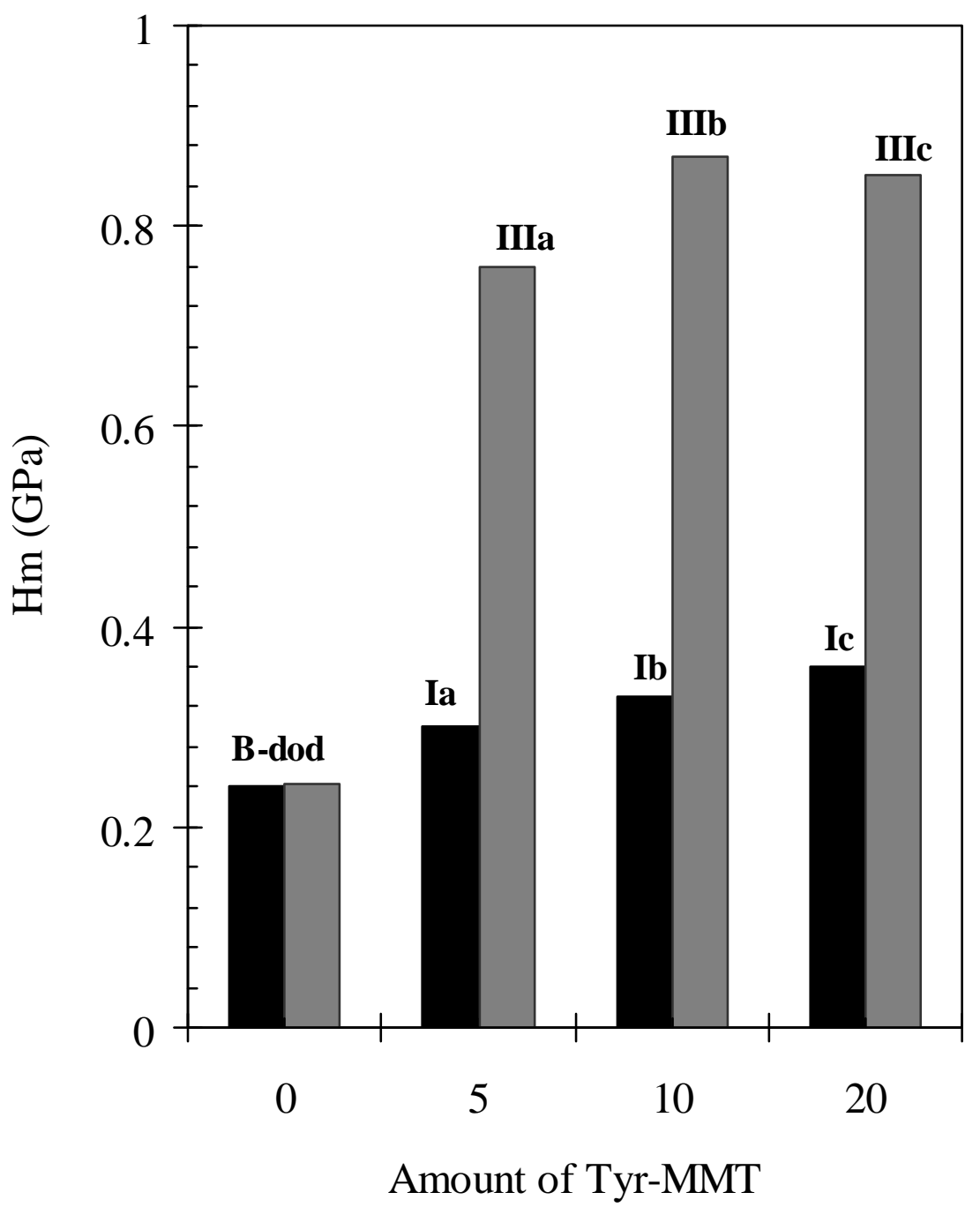

Figure 14 


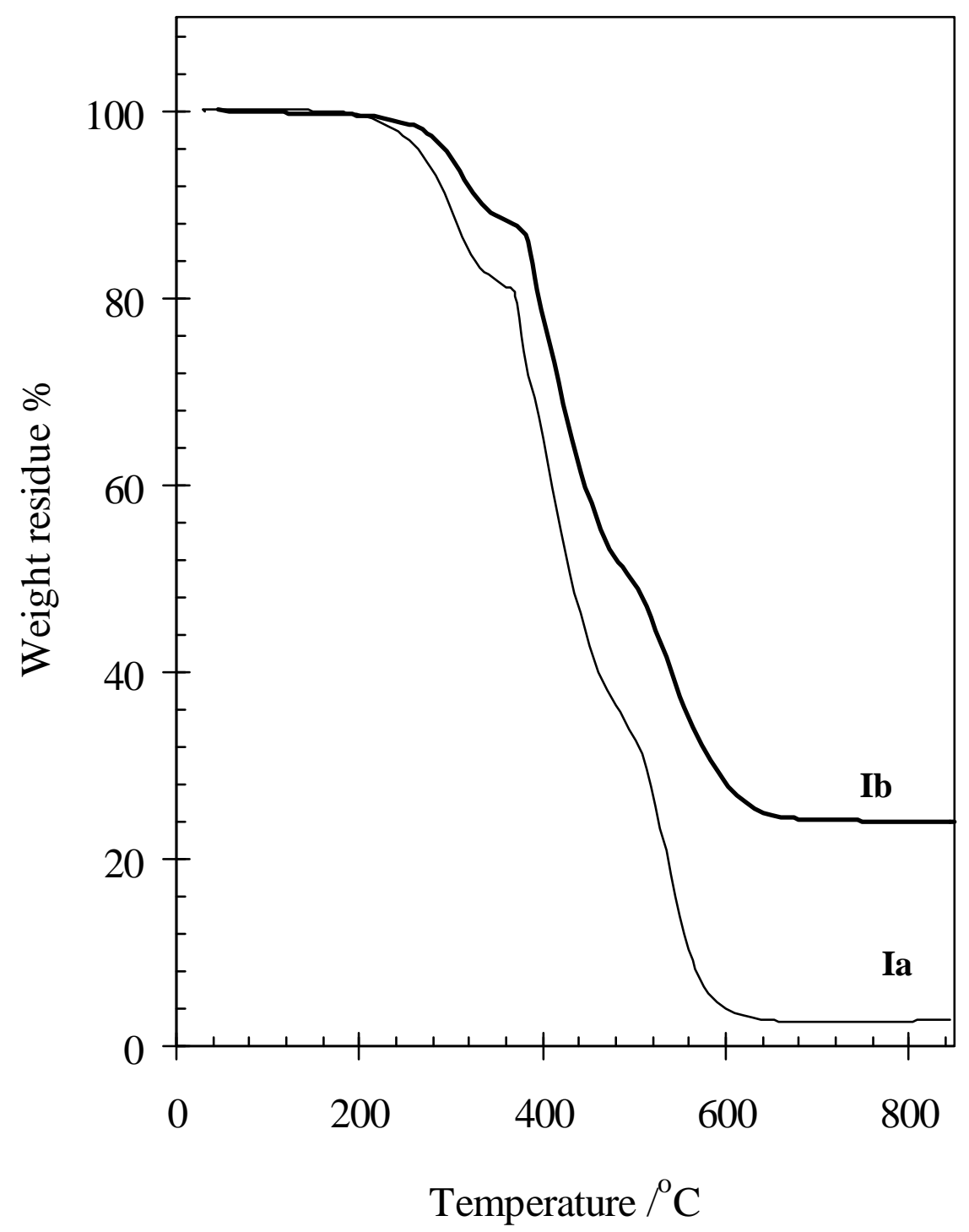

Figure 15 


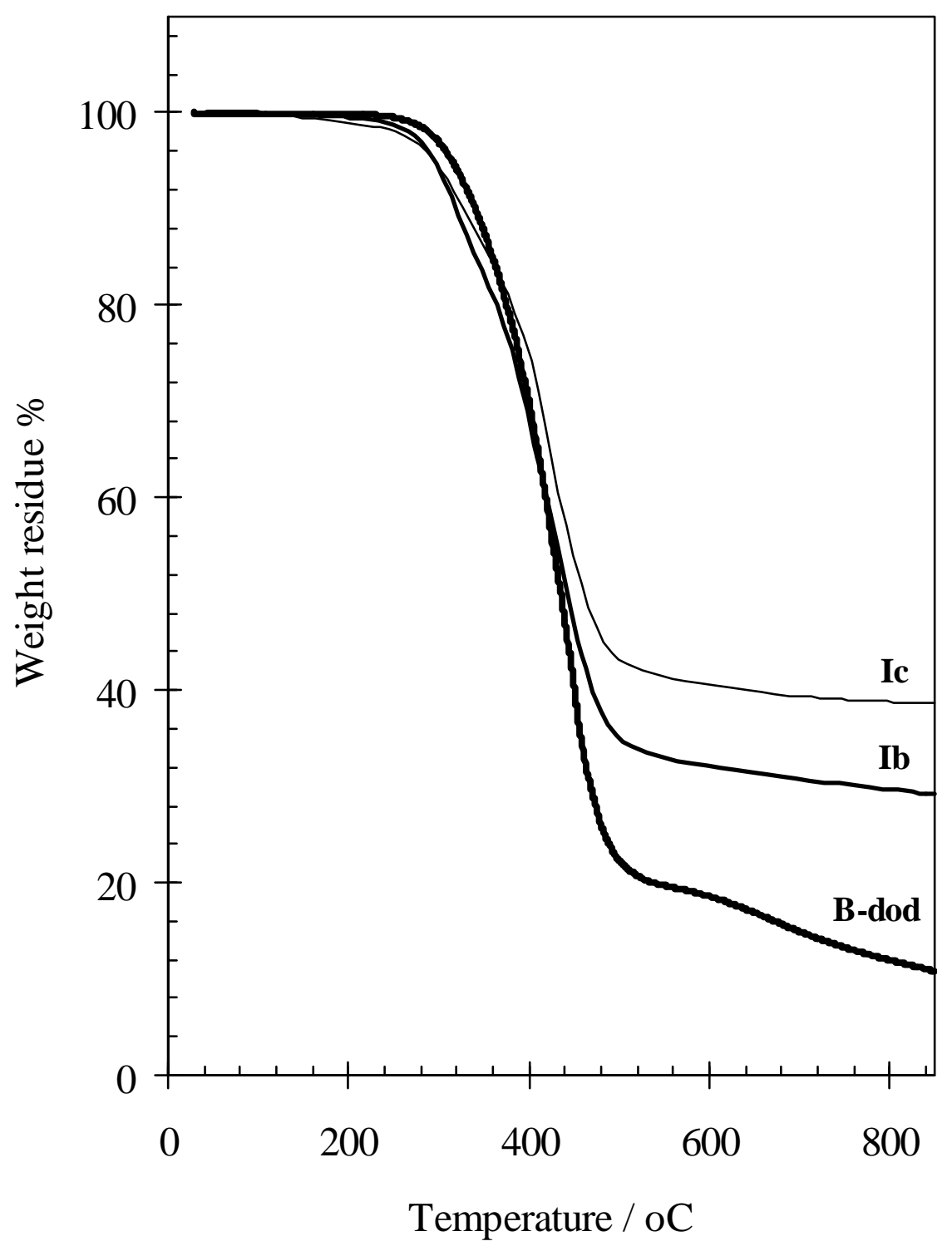

Figure 16 


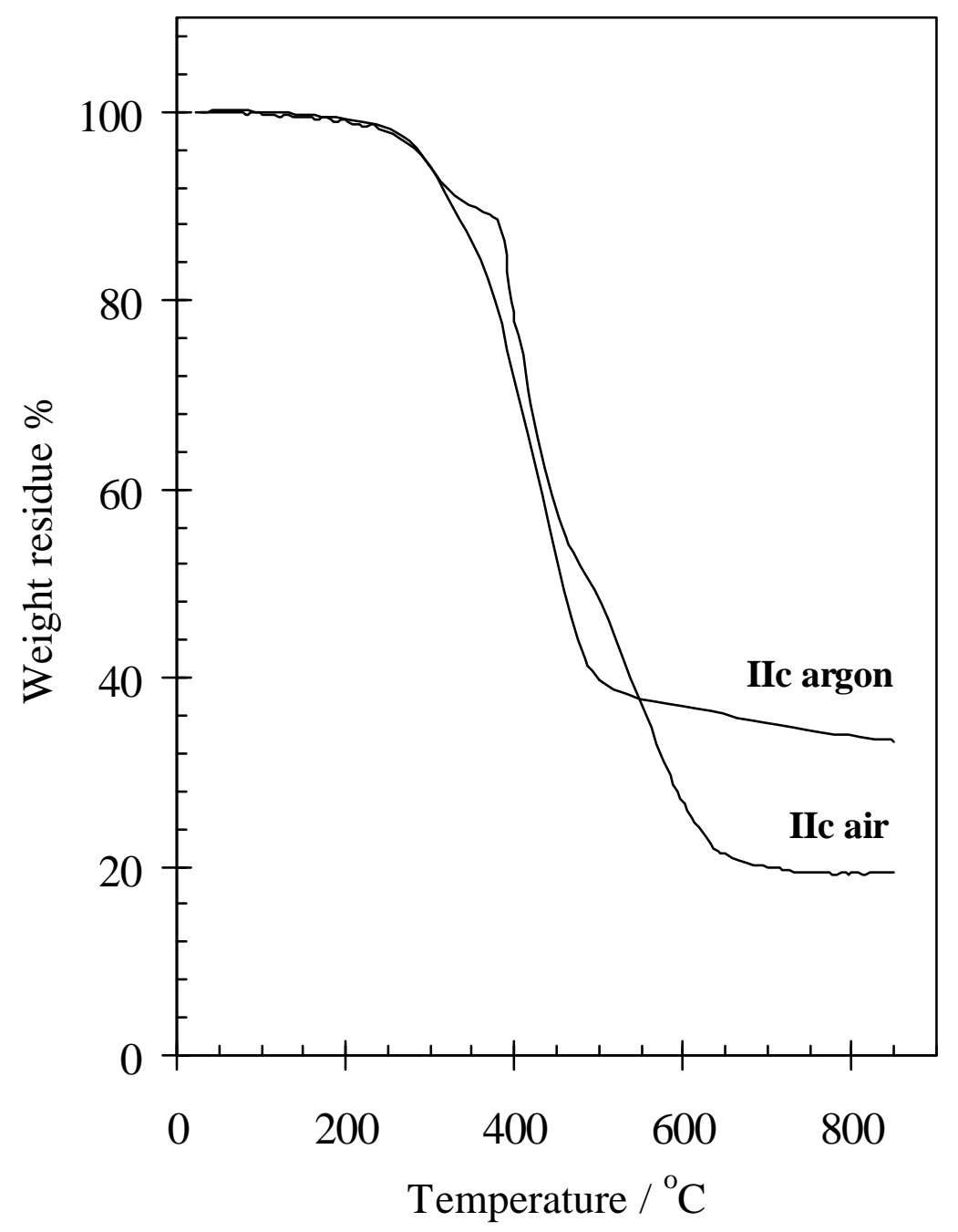

Figure 17 


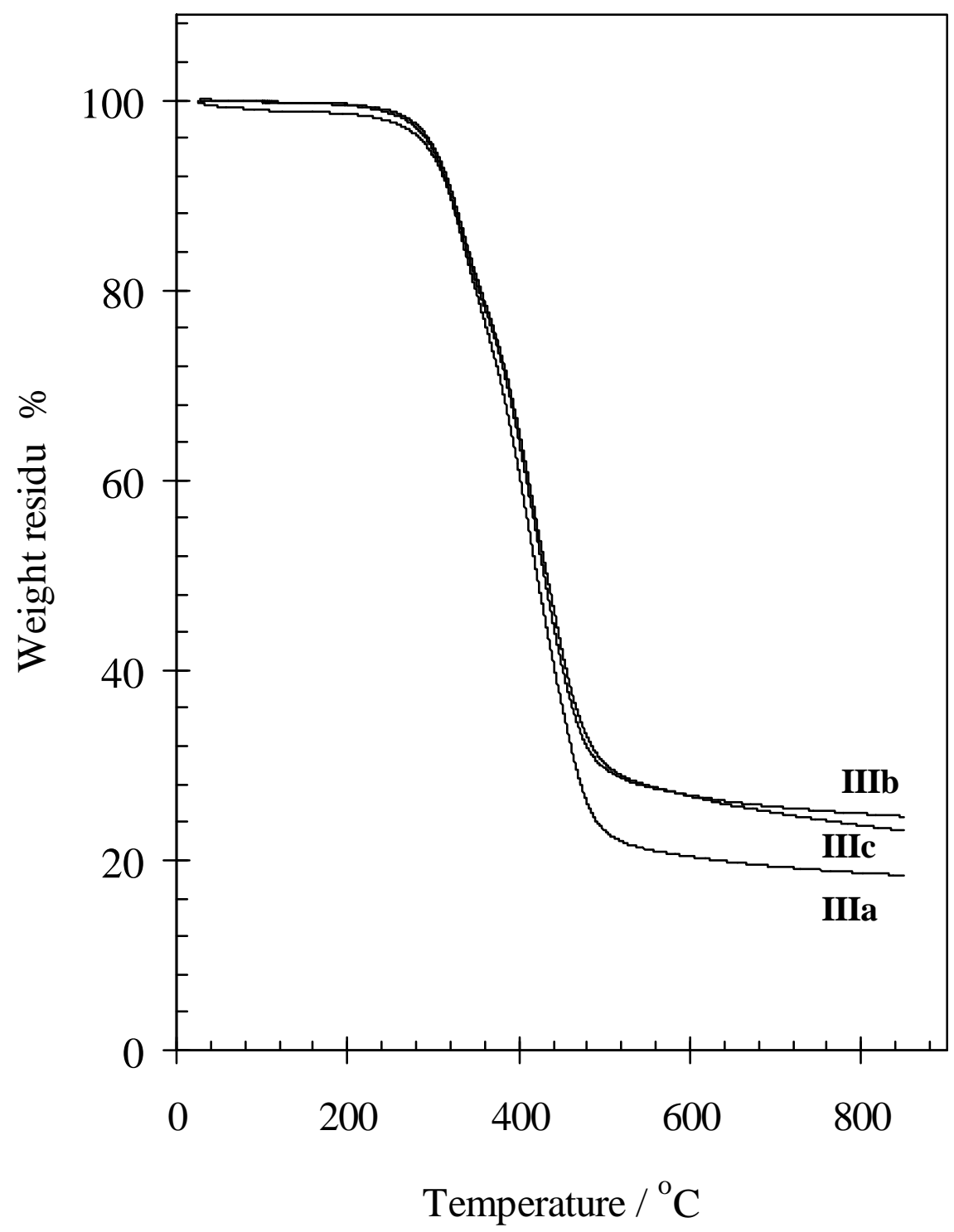

Figure 18 


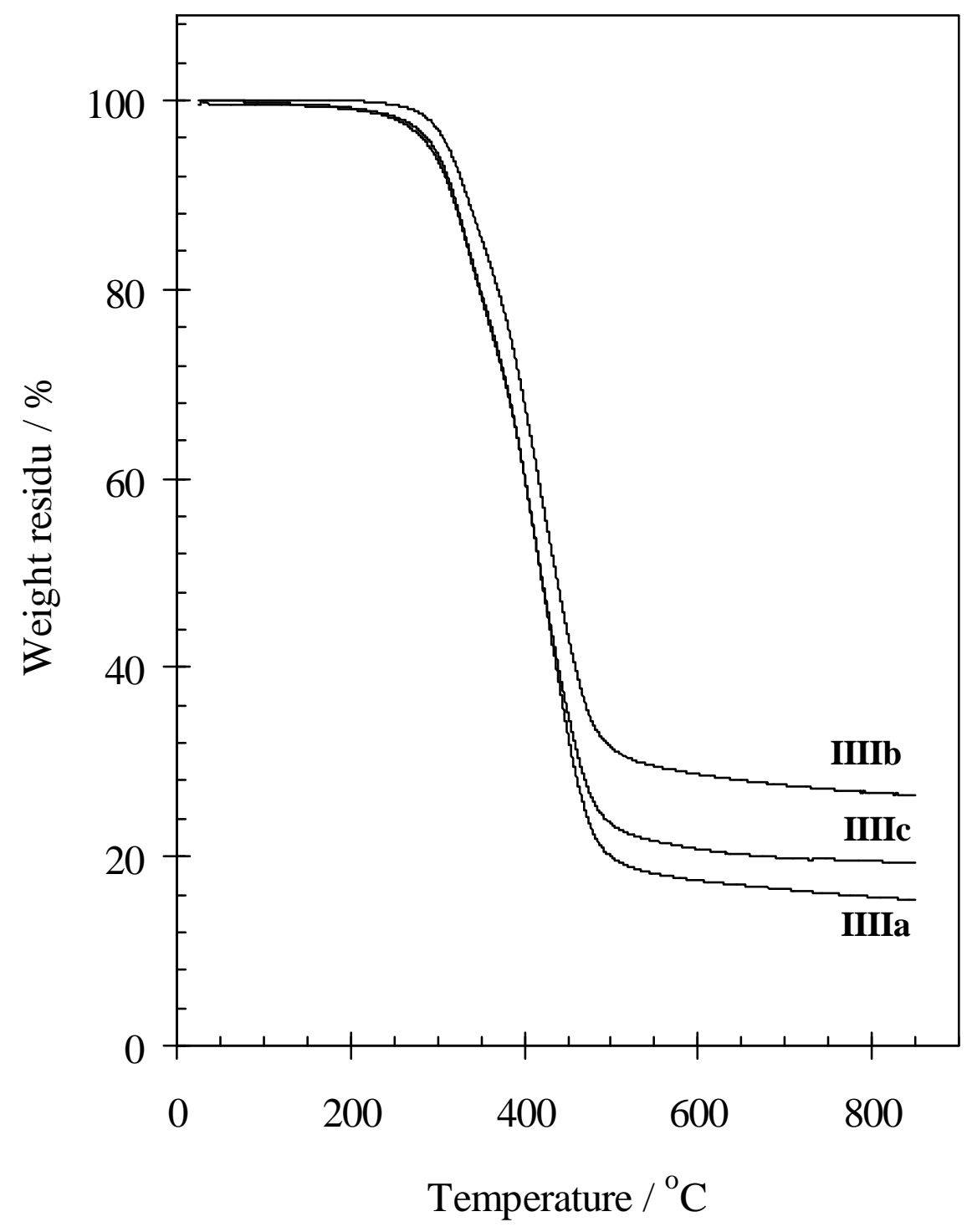

Figure 19 